\title{
Modeling and Optimising the Growth of Lasiodiplodia theobromae During Gathotan Fermentation
}

\author{
UMI PURWANDARI, NOVIA NAVA, AND DARIMIYYA HIDAYATI
}

\author{
Department of Agroindustrial Technology, Universitas Trunojoyo Madura
}

PO Box 2 Kamal, Madura, Indonesia 69162

\begin{abstract}
Gathotan is fungal fermented cassava, and a raw material for a Javanese snack called 'gathot'. This type of food is now hardly to find, and the process of making gathotan is relatively lack of process control, leads to failure in process. To make gathotan, peeled cassava tubers are left on the ground or roof for several weeks or months until they become black inside an important characteristic of gathotan. This work aims to improve gathotan fermentation by optimizing fermentation process. The effect of incubation temperature and time, inoculum level, soaking time, and drying, on the growth of Lasiodiplodia theobromae, the main gathotan fungus, in cassava tubers was studied. Experimental design was set up according to response surface methodology. Five parameters measured were $\mathrm{pH}$, titratable acidity, and fungal growth. Results showed that incubation temperature affected $\mathrm{pH}$ in linear $(\mathrm{P}<0.01)$ and quadratic functions $(\mathrm{P}<0.05)$. Titratable acidity was not affected by any treatment. Fungal growth was significantly affected by incubation time $(\mathrm{P}<0.01)$ or inoculum level $(\mathrm{P}<0.05)$, and interaction of several factors: incubation time and incubation temperature $(\mathrm{P}<0.05)$ or drying time $(\mathrm{P}<0.01)$. Optimization model indicated that incubation temperature at $34.5^{\circ} \mathrm{C}$ for 2.4 days, soaking for 26.4 hours, drying time of 3.7 hours at $40^{\circ} \mathrm{C}$, and inoculum level of $2 \%$ resulted in maximum growth of $L$. theobromae in gathotan.
\end{abstract}

Key words: gathotan, Lasiodiplodia theobromae, fermentation

Gathotan adalah singkong yang terfermentasi oleh jamur, dan merupakan bahan mentah jajan tradisional Jawa yang bernama 'gathot'. Makanan ini saat ini sulit ditemukan di pasaran, dan proses pembuatan gathotan umumnya tidak memiliki pengendalian proses yang cukup baik, sehingga kegagalan proses sering terjadi. Gathotan dibuat dengan cara mengupas singkong, lalu membiarkannya di permukaan tanah atau di atas atap rumah beberapa minggu atau beberapa bulan sehingga menjadi berwarna hitam di dalamnya. Warna hitam merupakan salah satu ciri penting gathotan. Penelitian ini bertujuan mengoptimasi proses fermentasi gathotan. Dikaji pengaruh suhu dan waktu inkubasi, kadar inokulum, dan waktu perendaman terhadap pertumbuhan Lasiodiplodia theobromae, jamur utama pada gathotan, di singkong. Rancangan percobaan disusun mengikuti rancangan pada metodologi permukaan tanggap. Ada lima parameter yang diukur, yaitu $\mathrm{pH}$, keasaman tertitrasi, dan pertumbuhan jamur. Hasil menunjukkan bahwa suhu inkubasi mempengaruhi $\mathrm{pH}$ sesuai fungsi linear $(\mathrm{P}<0.01)$ dan kuadratik $(\mathrm{P}<0.05)$. Keasaman tertitrasi tidak dipengaruhi oleh perlakuan. Pertumbuhan jamur dipengaruhi oleh waktu inkubasi $(\mathrm{P}<0.01)$ atau kadar inokulum $(\mathrm{P}<0.05)$, atau interaksi beberapa faktor berikut: waktu dan suhu inkubasi $(\mathrm{P}<0.05)$ atau waktu inkubasi dan waktu pengeringan $(\mathrm{P}<0.01)$. Model optimasi menunjukkan bahwa suhu inkubasi pada $34,5^{\circ} \mathrm{C}$ selama 2,4 hari, perendaman selama 26,4 jam, pengeringan selama 3,7 jam pada suhu $40^{\circ} \mathrm{C}$, dan kadar inokulum $2 \%$ memberikan hasil pertumbuhan jamur L. theobromae maksimum.

Kata kunci : gathotan, Lasiodiplodia theobromae, fermentasi

Gathotan is dried fermented cassava tuber, seemingly mostly found in Central and East Java, Indonesia. Fungal types and distribution in gathotan has been reported previously (Purwandari 2000), consisting of spore forming hypomycetes on surface, and Lasiodiplodia theobromae -a dematiaceous fungus- the dominant fungus grew inside the tuber. Dominant spore-forming hypomycetes are Rhizopus oryzae and Aspergillus flavus. Gathotan is characterized by black colour which comes mostly from mycelia of $L$. theobromae, since it is the only

*Corresponding author; Phone: +62-31 3011146, Fax: +61313011506; email: umipurwandari@yahoo.com fungus having dark colour of hyphae and the fungus isolated mostly from the inside part of gathotan (Purwandari 2000). Pairing L. theobromae with either $R$. oryzae or A. flavus on three types of plate agar (DG18/dichloran glycerol agar, AFPA/A. flavusparasiticus agar, and MEA/malt extract agar) consistently shows dominant growth of L. theobromae and restricted growth of the other fungus (Purwandari $2000)$. In the beginning of growth stage, $R$. oryzae is dominating over L. theobromae, but on the later stage of growth, L. theobromae grows overcompeted $R$. oryzae.

Gathot, the cooked gathotan, is characterised by its chewy texture. The chewy nature may relate to the 
change in starch nature. Such change maybe due to enzyme(s) or acid produced by fungus/fungi. $L$. theobromae is potentially a producer of a starch hydrolizing enzyme called glucoamylase (Navaratman et al. 1996) to result in D-glucose and degraded starch fraction. One possibility of starch fraction is dextrin, a hydrocolloid.

The chewy nature of gathot enables it to be used as raw material of gluten-free noodle (Purwandari et al. $2014 b$ ), since elasticity is a very essential characteristic of noodle. Moreover, gathotan flour has also been used as texturing agent of various gluten-free noodle made from some types of tubers or starchy fruit such as breadfruit (Purwandari et al. 2014a). Gathotan noodle has been identified for several health-relating benefits including hypoglycemic and antioxidant properties (Purwandari et al. 2014c). The hypoglycemic effect of gathotan noodle may come from fermentation product of starch during gathotan making, while antioxidant activity may come from melanin produced by $L$. theobromae (Purwandari et al. 2014c).

The growth of $L$. theobromae in gathotan can raise health concern, since the fungus is a plant pathogen. It is an important plant pathogen, and highly prevalent in the tropical areas. Factors affecting growth of the fungus have been reported with reference to tropical tuber (Kihurani et al. 2008) or fruits (Mortuza and Ilag 1999; Muniz et al. 2011; Sivakumar et al. 2011; Pawar 2012), such as temperature, water activity, and UV exposure (Uduebo and Madelin 1974). Antagonistic studies of several microorganisms against $L$. theobromae has also been reported, which involves fungi (Mortuza and Ilag 1999; Haggag and Nofal 2006; Fadahunsi et al. 2013), yeast (Hashem and Alamri 2009), or bacteria (Fadahunsi et al. 2013; Sajitha et al. 2014). So far, there is no study in the area of safety of gathot in relation to L. theobromae growth. However, there seems to be no report on incidence of gathot toxicity caused by the fungus. Instead, one may start thinking of potential health benefits can be generated by the growth of $L$. theobromae in gathot, such as anticancer (Pandi et al. 2010), anti-thrombotic (Vasconcelos et al. 2013), and antioxidant (Giese et al. 2015). The fungus also produces $\beta$-D-glucan called lasiodiplodin with several functional properties (Vasconcelos et al. 2013).

Although growth of $L$. theobromae as plant pathogen has been extensively studied, its growth during gathotan fermentation does not seem to attract much attention. Traditionally, gathotan making process is conducted without any addition of inoculum, thus allowing different types of soil fungi including those antagonistic to $L$. theobromae, grow during the process (Purwandari 2000). This can lead to failure in the fermentation, or very little $L$. theobromae grows in the tuber, a common problem faced by gathotan makers. Therefore, this work is dedicated to construct a model and to optimise the growth of $L$. theobromae during gathotan fermentation, using gathotan powder as inoculum.

\section{MATERIALS AND METHODS}

Materials. Raw material for gathotan making is fresh cassava tuber. The tuber was purchased commercially from local market in Kamal, Madura. The tubers were intact without any sign of cut. It had white flesh, and diameter of base of tuber varied between 3 to $5 \mathrm{~cm}$. Typical commercial cassava is characterised by relatively low water content and optimum starch content, without fibrous part in the flesh. Tuber was free from any defect caused either by biochemical reaction so called 'vascular streak', or signs of visible microbial growth. The second material was gathotan powder. Gathotan chunk taken from previous batch was characterised by black colour covering more than $50 \%$ of inside part of tuber. The chunks were washed with running tap water, until washing water became clean, did not show discolouration of tuber. Washed gathotan chunk was then dried in a cabinet dryer at $40^{\circ} \mathrm{C}$ for one hour, after which it was ground with a mechanical grinder. The flour resulted from grinding was passed through 60 mesh sieve, and this flour was used as inoculum in the experiment. Black part inside gathotan is the place for the growth of L. theobromae (Purwandari 2000).

Cassava Tubers Preparation. Tubers were peeled, and washed thoroughly with tap water three times to ensure they were free from dirt, and cut into about $10 \mathrm{~cm}$ long chunks. The chunks were drained well, and then treated according to experimental design.

Fermentation of Gathotan. The next step was soaking the tubers in tap water, according to experimental design: $0,12,24,36$, and 48 hours. After soaking, tubers were again washed to remove soaking water from tubers. Tubers were then dried in a cabinet dryer $\left(40^{\circ} \mathrm{C}\right)$ for several hours according to experimental design: 1, 2, 4, and 6 hours. After that, tubers were mixed thoroughly with gathotan suspension (gathotan powder : distilled water, 1:2, $\mathrm{w} / \mathrm{w})$. Level of inoculum used in the experiment was 2 , 
$3,4,5$ and $6 \%(\mathrm{w} / \mathrm{w})$ of fresh cassava tubers. Then $1 \mathrm{~kg}$ of tubers of each treatment combination were placed in a sterile $5 \mathrm{~L}$ plastic container. The plastic container was then incubated at different temperatures: $27,30,35,37$, and $40{ }^{\circ} \mathrm{C}$, according to experimental design. Incubation time was 2, 3, 4, 5, and 6 days.

Response Surface Methodology Observation. Experimental design was constructed according to Response Surface Methodology, using five factors (soaking time, drying time, inoculum level, incubation time, and incubation temperature), with five levels for each factor. During fermentation, samples were taken for examination on $\mathrm{pH}$, total acidity, and growth of $L$. theobromae. Determination of $\mathrm{pH}$ of gathotan chunk was carried out using electronic $\mathrm{pH}-$ meter. Gathotan chunk was first washed by spraying chunk with distilled water thoroughly to remove excess of soaking water. Then, chunk was put in a blender, and was added with distilled water 5 times of weight of sample. It was then blended for around 3 minutes, until slurry was formed. The slurry was then passed through a number 40 Whatman filter paper to collect filtrate. Filtrate was examined for $\mathrm{pH}$, using $\mathrm{pH}$ meter. The same slurry was examined for titratable acidity, by first added with $1 \mathrm{~mL}$ of $1 \%$ phenolphtalein, and then titrated with $1 \mathrm{~N} \mathrm{NaOH}$. Titratable acidity was expressed as percentage of lactic acid. Fungal growth examination was carried out by examining the presence of hyphae of $L$. theobromae inside tubers, using a light microscope connected with a camera (Olympus CX31 LED, Japan) and a PC. Mycelium of $L$. theobromae is septate and grows parallel to longitudinal rays (Muniz et al. 2011). Tuber chunk was dissected using a manual microtome without freezing the sample. The dissected piece was divided into three sections towards center.

Zone Division. First section (zone A) was the outer part one-third near the surface of tuber. The middle section (zone B) was between one-third area from surface and one-third was from the center of tuber. Zone $\mathrm{C}$ was one-third area from the center of tuber.

Statistical Calculation. Statistical analysis was performed on Minitab ${ }^{\circledR} 14$ (Minitab Inc., Pensylvania, USA) for response surface methodology, employing a quadratic equation. Response was expressed as following equation:

$$
\begin{aligned}
& \qquad Y=\beta_{0}+\beta_{11} X_{1}^{2}+\beta_{22} X_{2}^{2}+\beta_{33} X_{3}^{2}+\beta_{44} X_{4}^{2}+\beta_{55} X_{5}^{2} \\
& +\beta_{1} X_{1}+\beta_{2} X_{2}+\beta_{3} X_{3}+\beta_{4} X_{4}+\beta_{5} X_{5}+\beta_{12} X_{1} X_{2}+ \\
& \beta_{13} X_{1} X_{3}+\beta_{14} X_{1} X_{4}+\beta_{15} X_{1} X_{5}+\beta_{23} X_{2} X_{3}+\beta_{24} X_{2} X_{4}+\beta_{25} \\
& X_{2} X_{5}+\beta_{34} X_{3} X_{4}+\beta_{35} X_{3} X_{5}+\beta_{45} X_{4} X_{5}+\varepsilon \ldots .(1) \\
& \text { where, } Y \text { was response (pH, total acidity, or fungal }
\end{aligned}
$$

mycelia), $\mathrm{X}_{1}$ was incubation temperature $\left({ }^{\circ} \mathrm{C}\right), \mathrm{X}_{2}$ was drying time (hour), $X_{3}$ was inoculum level (\% w/w), $X_{4}$ was soaking time (hours), and $X_{5}$ was incubation time (days).

\section{RESULTS}

pH. Result on pH of gathotan chunk throughout fermentation showed that $\mathrm{pH}$ was influenced significantly $(\mathrm{P}<0.01)$ only by linear and quadratic function of incubation temperature (Table 1), and $\mathrm{pH}$ was not affected significantly ( $\mathrm{P} \geq 0.05)$ by other factors such as drying time nor inoculum level, following the equation:

$$
\mathrm{pH}=31.3043+0.0160 \mathrm{X}_{1}^{2}-0.0396 \mathrm{X}_{2}^{2}-0.0509 \mathrm{X}_{3}^{2}
$$
$-0.0002 \mathrm{X}_{4}^{2}-0.0071 \mathrm{X}_{5}^{2}+1.3165 \mathrm{X}_{1}-0.0075 \mathrm{X}_{2}$ $0.9866 X_{3}+0.0177 X_{4}-1.0465 X_{5}+0.0047 X_{1} X_{2}+$ $0.0352 X_{1} X_{3}+0.0003 X_{1} X_{4}+0.0185 X_{1} X_{5}--0.0644$ $\mathrm{X}_{2} \mathrm{X}_{3}+0.0002 \mathrm{X}_{2} \mathrm{X}_{4}+0.0625 \mathrm{X}_{2} \mathrm{X}_{5}+0.0004 \mathrm{X}_{3} \mathrm{X}_{4}+$ $0.0625 \mathrm{X}_{3} \mathrm{X}_{5}-0.0625 \mathrm{X}_{4} \mathrm{X}_{5} \ldots$ (2)

where, $\mathrm{X}_{1}$ was incubation temperature $\left({ }^{\circ} \mathrm{C}\right), \mathrm{X}_{2}$ was drying time (hour), $X_{3}$ was inoculum level (\% w/w), $X_{4}$ was soaking time (hours), and $\mathrm{X}_{5}$ was incubation time (days).

High regression coefficient of incubation temperature (1.3165), fermentation time (-1.0465), and inoculum level $(-0.9866)$ showed that the three factors affected $\mathrm{pH}$ of gathotan in a relatively considerable extent. The correlation between $\mathrm{pH}$ and incubation temperature was negative, indicating that $\mathrm{pH}$ was lowered by increasing temperature during fermentation. Contrary, longer fermentation time or higher inoculum level reduced $\mathrm{pH}$. The coefficient of determination for $\mathrm{pH}$ was $72.24 \%$ (data not shown), indicating relatively high sufficiency of model.

Incubation temperature between 35 to $40{ }^{\circ} \mathrm{C}$ resulted in final $\mathrm{pH}$ of 4.5 (Fig 1). Incubation at room temperature to $34{ }^{\circ} \mathrm{C}$ resulted in $\mathrm{pH}$ between 7 to 5 . Similarly, at high level of inoculum (6\%), low pH at 4.8 could be reached at incubation temperature of $32{ }^{\circ} \mathrm{C}$ (data not shown). Although statistically not significant $(\mathrm{P} \geq 0.05)$, lower drying time seemed to reduce $\mathrm{pH}$ at high incubation temperature near $40{ }^{\circ} \mathrm{C}$ (data not shown).

Titratable Acidity. In contrast to $\mathrm{pH}$, titratable acidity was not affected significantly $(\mathrm{P} \geq 0.05)$ by any factor examined. Regression model for titratable acidity was as follows:

Titratable acidity $=-1.3199-0.0009 \mathrm{X}_{1}^{2}+0.0006$ $X_{2}^{2}+0.0032 X_{3}^{2}-0.00004 X_{4}^{2}+0.0012 X_{5}^{2} 0.0776 X_{1}-$ 
Table $1 \mathrm{pH}$ of cassava chunk during fermentation of gathotan

\begin{tabular}{|c|c|c|c|c|c|c|}
\hline \multirow[t]{2}{*}{ Source } & \multicolumn{2}{|l|}{$\mathrm{pH}$} & \multicolumn{2}{|c|}{ Titratable acidity } & \multicolumn{2}{|c|}{$\begin{array}{l}\text { Fungal growth in } \\
\text { zone A }\end{array}$} \\
\hline & Coefficient & $\mathrm{P}$ & Coefficient & $\mathrm{P}$ & Coefficient & $\mathrm{P}$ \\
\hline Constant & 31.3043 & 0.004 & -1.31990 & 0.152 & -60.0810 & 0.141 \\
\hline Incubation temperature & $-1.3165^{*}$ & 0.010 & 0.07765 & 0.092 & 1.5516 & 0.426 \\
\hline Drying time & 0.0075 & 0.994 & 0.02336 & 0.805 & -6.4361 & 0.145 \\
\hline Inoculum level & -0.9866 & 0.335 & -0.02380 & 0.811 & $9.8713 *$ & 0.043 \\
\hline Soaking time & 0.0177 & 0.824 & -0.00020 & 0.979 & -0.6726 & 0.075 \\
\hline Incubation time & $-1,0465$ & 0.308 & 0.08526 & 0.399 & $14.0059 *$ & 0.008 \\
\hline Incubation temperature * Incubation temperature & $0.0160 *$ & 0.022 & -0.00098 & 0.130 & -0.0083 & 0.762 \\
\hline Drying time $*$ Drying time & -0.0396 & 0.518 & 0.00061 & 0.919 & -0.3822 & 0.173 \\
\hline Inoculum level $*$ Inoculum level & -0.0509 & 0.410 & 0.00324 & 0.594 & -0.1322 & 0.624 \\
\hline Soaking time $*$ Soaking time & -0.0002 & 0.635 & -0.00004 & 0.349 & $0.0078 *$ & 0.001 \\
\hline Incubation time $*$ Incubation time & -0.0071 & 0.907 & 0.06124 & 0.838 & -0.5072 & 0.079 \\
\hline Incubation temperature $*$ Drying time & 0.0047 & 0.836 & -0.00091 & 0.689 & $0.4279 *$ & 0.001 \\
\hline Incubation temperature $*$ Inoculum level & 0.0352 & 0.142 & -0.00023 & 0.920 & $-0.2163^{*}$ & 0.050 \\
\hline Incubation temperature $*$ Soaking time & 0.0003 & 0.888 & -0.00001 & 0.964 & 0.0084 & 0.326 \\
\hline Incubation temperature $*$ Incubation time & 0.0185 & 0.424 & -0.00264 & 0.257 & $-0.2644 *$ & 0.021 \\
\hline Drying time* Inoculum level & -0.0644 & 0.439 & 0.00087 & 0.914 & -0.3125 & 0.397 \\
\hline Drying time*Soaking time & 0.0002 & 0.976 & 0.00019 & 0.783 & -0.0156 & 0.607 \\
\hline Drying time* Incubation time & 0.0550 & 0.507 & 0.00038 & 0.963 & $-1.1875^{*}$ & 0.006 \\
\hline Inoculum level*Soaking time & -0.0004 & 0.951 & 0.00021 & 0.759 & -0.0156 & 0.607 \\
\hline Inoculum level*Incubation time & 0.0625 & 0.453 & 0.00113 & 0.890 & 0.0625 & 0.863 \\
\hline Soaking time* Incubation time & -0.0042 & 0.541 & 0.00048 & 0.485 & 0.0365 & 0.243 \\
\hline
\end{tabular}

*indicated significance level of 0.05

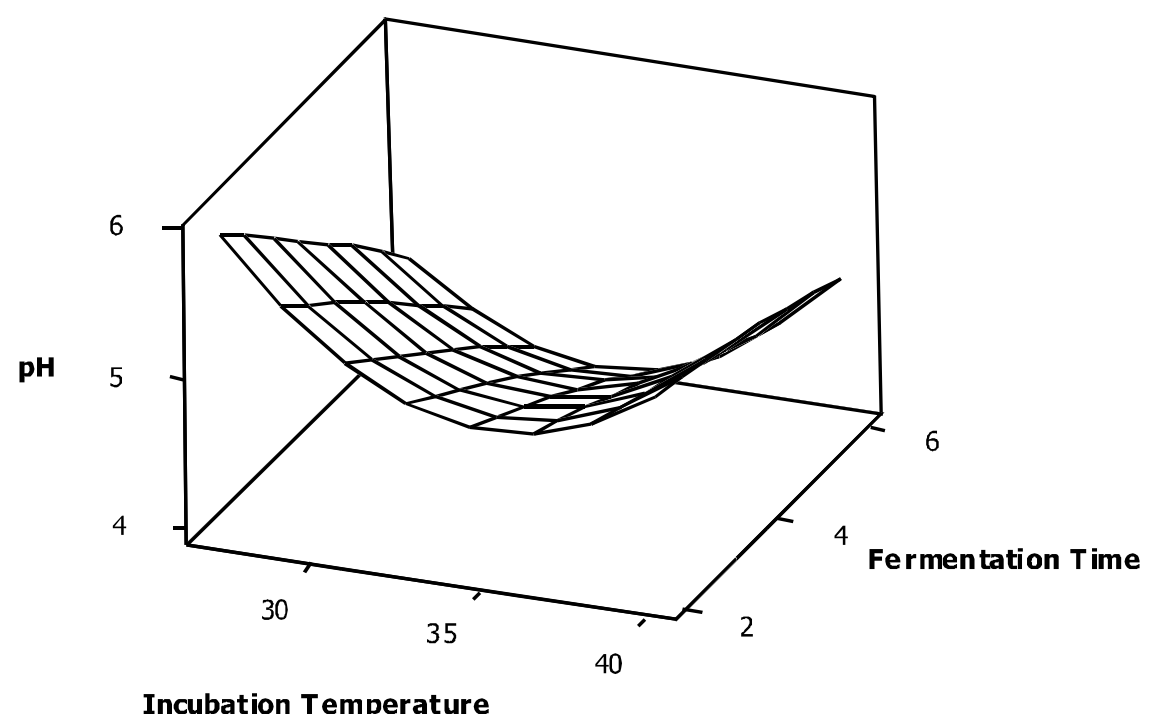

Fig 1 The effect of incubation temperature and incubation time on $\mathrm{pH}$ of cassava chunk during gathotan fermentation

$0.0233 X_{2}-0.0238 X_{3}-0.0002 X_{4}+0.0852 X_{5}-0.0009$ $\mathrm{X}_{1} \mathrm{X}_{2}-0.0002 \mathrm{X}_{1} \mathrm{X}_{3} 0.00001 \mathrm{X}_{1} \mathrm{X}_{4}-0.0026 \mathrm{X}_{1} \mathrm{X}_{5}+$ $0.0009 \mathrm{X}_{2} \mathrm{X}_{3}+0.0002 \mathrm{X}_{2} \mathrm{X}_{4}+0.0004 \mathrm{X}_{2} \mathrm{X}_{5}+0.0002$ $\mathrm{X}_{3} \mathrm{X}_{4}+0.0011 \mathrm{X}_{3} \mathrm{X}_{5} 0.0005 \mathrm{X}_{4} \mathrm{X}_{5} \ldots$ (3)

where, $\mathrm{X}_{1}$ was incubation temperature $\left({ }^{\circ} \mathrm{C}\right), \mathrm{X}_{2}$ was drying time (hour), $\mathrm{X}_{3}$ was inoculum level (\% w/w),
$\mathrm{X}_{4}$ was soaking time (hours), and $\mathrm{X}_{5}$ was incubation time (days).

Although all regression coefficients in Equation 3 were small, those of incubation temperature (-0.0776) and fermentation time $(0.0852)$ were relatively greater then the others. While higher incubation temperature 
resulted in reducing titratable acidity, longer incubation time led to the increase in titratable acidity. Coefficient of determination for titratable acidity was $65.97 \%$ (data not shown), indicating that data fitted model relatively well.

Surface plot of incubation temperature against fermentation time indicated that high temperature from 36 to $40^{\circ} \mathrm{C}$ resulted in high titratable acidity (Fig 2). Similarly, high temperature $\left(30\right.$ to $\left.36^{\circ} \mathrm{C}\right)$ and longer incubation time also caused high concentration of titratable acidity. Inoculum level at $3 \%$ also gave high titratable acidity (data not shown).

Fungal Growth. Fungal growth was expressed as the number of $L$. theobromae hyphae inside gathotan. Hyphae of $L$. theobromae looked as relatively large septate hyaline hyphae that grew parallel to vascular tissue. Every parallel hyphae of the fungus was counted as one hyphae. Young hyphae of $L$. theobromae is hyaline, and becomes dark, grey, or black in later stage of growth (Alasoadura 1970). Data of the number of hyphae of $L$. theobromae growth inside cassava chunk during fermentation of gathotan was only meaningful when in zone A. The model for fungal colonization in zone $\mathrm{B}$ and $\mathrm{C}$ showed negative number of hyphae, thus possibly indicated unreliable model correlatively absence of fungus in the area. Therefore, data on the number of hyphae in zone B and $\mathrm{C}$ were not analysed further. Regression equation for mycelial growth in zone A was:

Number of hyphae $=-60.0810-0.0083 \mathrm{X}_{1}^{2}-$ $0.3822 \mathrm{X}_{2}^{2}-0.1322 \mathrm{X}_{3}^{2}+0.0078 \mathrm{X}_{4}^{2}-0.5072 \mathrm{X}_{5}^{2}-$ $1.5516 X_{1}-6.4361 X_{2}+9.8713 X_{3}-0.6726 X_{4}+$ $14.0059 X_{5}+0.4279 X_{1} X_{2}-0.2163 X_{1} X_{3}+0.0084 X_{1} X_{4}$ - $0.2644 X_{1} X_{5}-0.3125 X_{2} X_{3}-0.0156 X_{2} X_{4}-1.1875$ $\mathrm{X}_{2} \mathrm{X}_{5} 0.0156 \mathrm{X}_{3} \mathrm{X}_{4}+0.0625 \mathrm{X}_{3} \mathrm{X}_{5}-0.0365 \mathrm{X}_{4} \mathrm{X}_{5} \ldots$. (4) where, $\mathrm{X}_{1}$ was incubation temperature $\left({ }^{\circ} \mathrm{C}\right), \mathrm{X}_{2}$ was drying time (hour), $X_{3}$ was inoculum level (\% w/w), $X_{4}$ was soaking time (hours), and $\mathrm{X}_{5}$ was incubation time (days).

High regression coefficients were shown by fermentation time (14.0059) and inoculum level (9.8713), indicating significant role of the two factors in determining fungal growth, with positive correlation. Coefficient of determination for the equation was $88.62 \%$, reflecting good fitness of data to the regression.

The number of hyphae in zone A was affected positively and significantly by inoculum level $(\mathrm{P}<0.05)$ and incubation time $(\mathrm{P}<0.01)$ (Table 1). Several interactions between factors showed significant effect were: quadratic function of soaking time $(\mathrm{P}<0.005)$, interaction between incubation temperature and drying time $(\mathrm{P}<0.005)$, incubation temperature and incubation time $(\mathrm{P}<0.05)$, and incubation time and drying time $(\mathrm{P}<0.01)$. No mycelium was detected during the first three days,

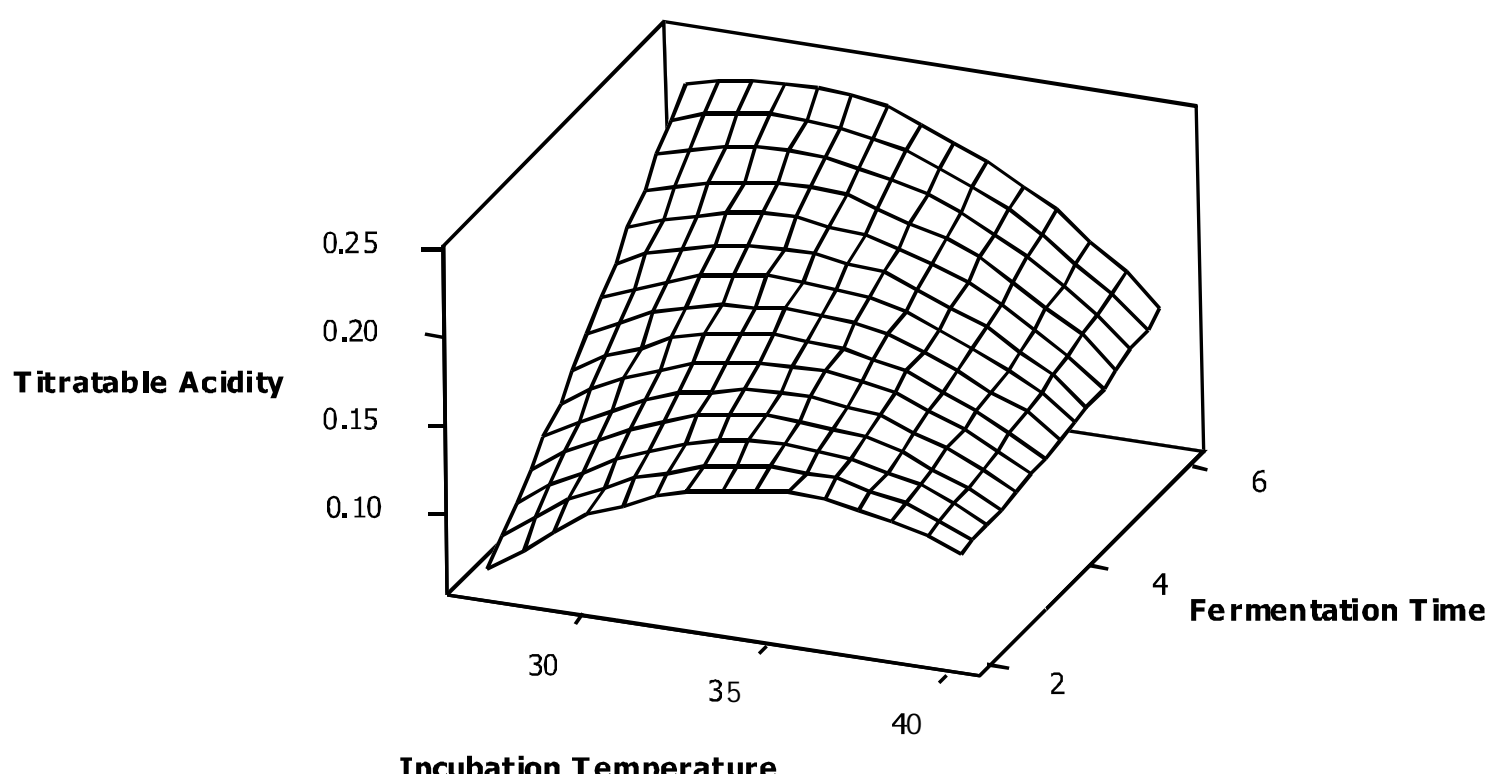

Incubation Temperature

Fig 2 The effect of incubation temperature and fermentation time on titratable acidity of cassava chunk during gathotan fermentation 


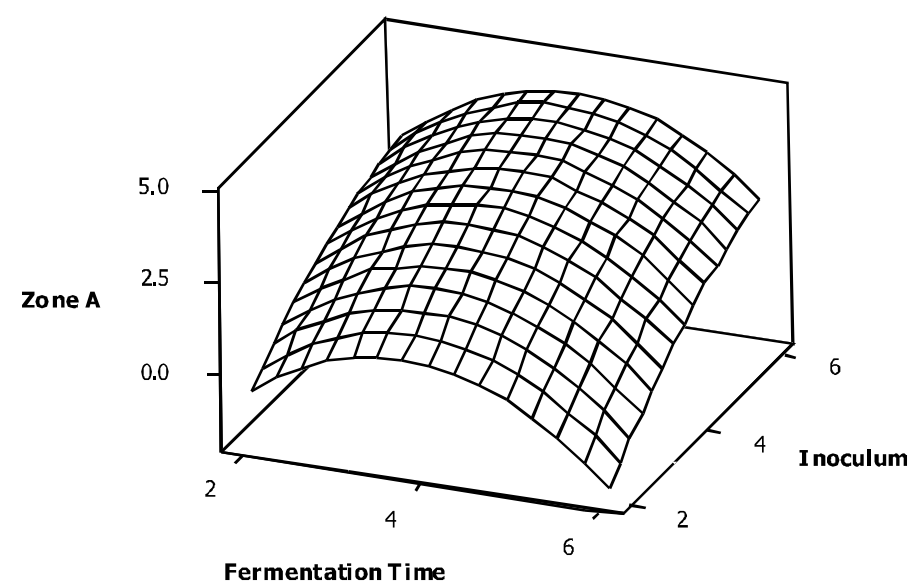

Fig 3 Growth of Lasiodiplodia theobromae during gathotan fermentation as affected by incubation time and inoculum level

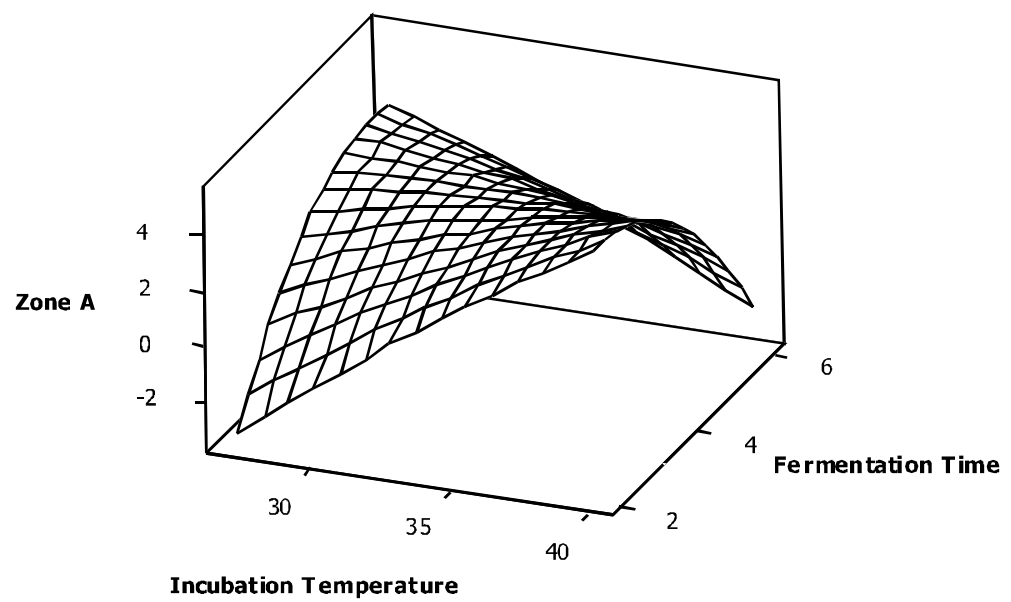

Fig 4 Growth of Lasiodiplodia theobromae during gathotan fermentation as affected by incubation time and incubation temperature

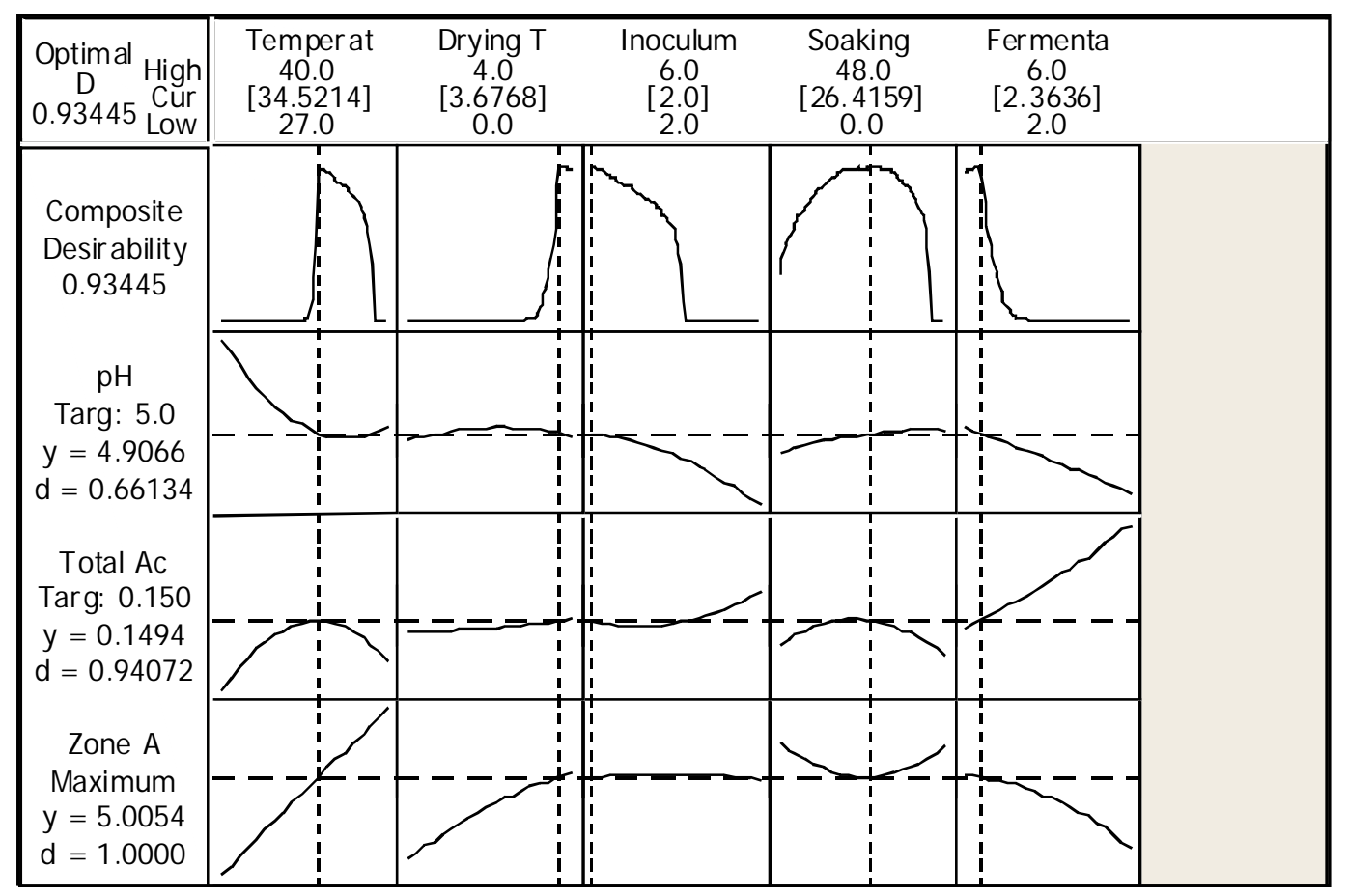

Fig 4 Optimization of conditions for Lasiodiplodia theobromae growth during gathotan fermentation 
when inoculum level was below $4 \%$. However, when inoculum level was high enough (over $5 \%$ ), hyphae started colonizing cassava as soon as two days incubation (Fig 3). Maximum fungal growth was reached after four days at $6 \%$ inoculum level, or six days at $4 \%$ inoculum level. Incubation temperature around $30{ }^{\circ} \mathrm{C}$ and fermentation time at $4 \mathrm{~d}$ or longer resulted in highest mycelium number (Fig. 4).

\section{DISCUSSION}

The changes of $\mathrm{pH}$ during gathotan fermentation was not as fast as when it was grown in liquid cassava medium with added nitrogen source (Navaratnam et al. 1996). In this liquid cassava medium, $\mathrm{pH}$ was lowered to reach $\mathrm{pH} 1.8$ during 50 hours of fermentation, showing a significant acid production by $L$. theobromae when nitrogen source was available (Navaratnam et al. 1996). Cassava is low in nitrogen content, so that $\mathrm{pH}$ reduction in gathotan fermentation was not as rapid as that in the liquid medium. Relatively slow $\mathrm{pH}$ reduction in gathotan fermentation seemed to be of benefit to the growth of $L$. theobromae, since the fungus grow well at relatively high $\mathrm{pH}$ (Eng et al. 1998). High $\mathrm{pH}$ reduction rate would not allow sufficient colonization of cassava tuber by the fungus, resulting in failure of fermentation. Previous report mentioned that mycelial production of $L$. theobromae was maximum at $\mathrm{pH} 8$ to 10 (Eng et al. 1998). The $\mathrm{pH}$ during gathotan fermentation did not seem to go lower than 4, thus allowed sufficient fungal growth inside tuber. Assuming that chewy texture of gathot, the cooked gathotan, is caused by glucoamylase activity, $\mathrm{pH}$ during gathotan fermentation (4-6) seems to support activity of the enzyme (Navaratnam et al. 1996), resulted in good and chewy gathot.

Titratable acidity indicates free proton neutralised during titration using a strong base solution. Titratable acidity also includes buffering capacity of sample (Rajkovic et al. 2007). Not all of hydrogen ions can be detected during titration, due to probable influence of monovalent cation exchange (Boulton 1980) and dissociation strength of acids. There was no significant difference of titratable acidity among our samples, although $\mathrm{pH}$ was different among gathotan samples. Measurement of $\mathrm{pH}$ was reported to be more reliable method to determine acidity in wine (Rajkovic et al. 2007). This may also apply to gathotan, where measurement of $\mathrm{pH}$ gives more meaningful information than titratable acidity.
Incubation temperature at around $30^{\circ} \mathrm{C}$ seemed to support growth of L. theobromae not only in gathotan fermentation, but also in various media. For example, in a liquid medium (Eng et al. 1998), cassavacontaining medium without any addition of nitrogen source (Navaratnam et al. 1996), potato dextrose agar medium (Kausar et al. 2009), and mango during postharvest (Pawar 2012). It was also reported that light was important to support growth of the fungus (Kausar et al. 2009). In our work, fermentation was conducted inside building with minimum light, so that growth of $L$. theobromae may not be at optimum level.

Gathotan fermentation was prone to contamination, as it is usually carried out in an open and unsterilized container. Some fungi are antagonistic to L. theobromae, such as some species of Trichoderma (Mortuza and Ilag 1999, Haggag and Nofal 2006, Fadahundi et al. 2013). One of antagonistic bacteria is $B$. subtilis which grows during soaking of cassava (Anyogu et al. 2014). A species of yeast, Pichia anomala restricts growth of L. theobromae (Hashem and Alamri 2009). Thus, reducing contamination of those antagonistic microorganisms is essential, and it can be carried out by improving sanitation of process. Lowering $\mathrm{pH}$ can inhibit bacterial contamination, but $\mathrm{pH}$ may not be allowed to be too low as it can inhibit growth of $L$. theobromae. Therefore, it is important to ensure fermentation conditions to support dominant growth of $L$. theobromae over antagonistic microorganisms.

We tried to determine optimum condition for growth of $L$. theobromae during gathotan fermentation. Using optimisation procedure, and by putting relative importance and weight of fungal colonization at 10 , titratable acidity at 2 and $\mathrm{pH}$ at 2 , we found that maximum fungal growth was achieved at incubation temperature of $34.5^{\circ} \mathrm{C}$ for 2.4 days, 3.7 hours drying at $40^{\circ} \mathrm{C}$, inoculum level of $2 \%$, and 26.4 hours soaking (Fig 5). Relative importance and weight is determined approximately to reflect distribution of desirability between lower or upper bound and the target value. The setting used in this optimization is evaluated by determining composite desirability value which is between 0 and 1 . Our setting resulted in composite desirability of 0.934 , indicating that the setting gave satisfactory results for all response as a whole. We noticed that during duration of fermentation in this work, there was no black fungal coloration of tubers, suggesting that additional time to allow maturation is needed in order to achieve final products with black colour characteristics of gathotan. 


\section{ACKNOWLEDGMENT}

This work is funded by Directorate General of High Degree Education, Ministry of Education and Culture, the Government of Indonesia, as research grant for "Penelitian Hibah Bersaing" scheme in 2014.

\section{REFERENCES}

Alasoadura SO. 1970. Culture studies on Botryodiplodia theobromae Pat. Mycopathol MycolAppl. 42(1-2):153-160.

Anyogu A, Awamaria B, Sutherland JP, Ouoba LIJ. 2014. Molecular characterisation and antimicrobial activity of bacteria associated with submerged lactic acid cassava fermentation. Food Control. 39:119-127. http://dx.doi.org/10.1016/j.foodcont.2013.11.005.

Boulton R. 1980. The relationships between total acidity, titratable acidity and $\mathrm{pH}$ in grape tissue. Vitis 19:113-120.

Eng F, Gutierrez-Rojas M, Favela-Torres E. 1998. Culture conditions for jasmonic acid and biomass production by Botyrodiplodia theobromae in submerged fermentation. Process Biochem. 33(7):715-720.

Fadahunsi I, Ayansina D, Okunrotifa A. 2013. Biocontrol of mushroom spoilage fungi and aflatoxin evaluation during storage. Nat and Sci. 11(7):7-13.

Giese EC, Gascon J, Anzelmo G, Barbosa AM, da Cunha MAA, Dekker RFH. 2015. Free-radical scavenging properties and antioxidant activities of botryosphaeran and some other B-D-glucans. Int J Biol Macromol 72:125-130. http://dx.doi.org/10.1016/j.ijbiomac. 2014.07.046.

Haggag WM, Nofal MA. 2006. Improving the biological control of Botryodiplodia disease on some Annona cultivars using single or multi-bioagents in Egypt. Biol Control.38:341-349.doi:10.1016/j.biocontrol.2006.02.010

Hashem M, Alamri S. 2009. The biocontrol of postharvest disease (Botryodiplodia theobromae) of guava (Psidium guajava L.) by the application of yeast strains. Postharvest Biol and Technol. 53:123-130. doi:10.1016/j.postharvbio.2009.04.001.

Kausar P, Chohan S, Parveen R. 2009. Physiological studies on Lasiodiplodia theobromae and Fusarium solani, the cause of Shesham decline. Mycopath. 7(1):35-38.

Kihurani AW, Narla RD, Shibairo S, Imungi J, Carey E. 2008. Effect of soil $\mathrm{pH}$ on postharvest pathological deterioration of sweet potato storage roots. Afr J Hort Sci 1:1-8.

Mortuza MG, Ilag LL. 1999. Potential for biocontrol of Lasiodiplodia theobromae (Pat.) Griff. \& Maubl. in banana fruits by Trichoderma species. Biol Control. 15:235-240.

Muniz CR, Freire FCO, Viana FMP, Cardoso JE, Cooke P, Wood D, Guedes MIF. 2011. Colonization of cashew plants by Lasiodiplodia theobromae: Microscopical features. Micron 42:419-428. doi:10.1016/j.micron. 2010.12.003.

Navaratnam $P$, Arasaratnam V, Mahendran S, Balasubramaniam K. 1996. Formulation of medium and recycling of biomass for glucoamylase production of Botryodiplodia theobromae. Process Biochem. 31(1):77-80.

Pandi M, Manikandan R, Muthumary J. 2010. Anticancer activity of fungal taxol derived from Botryodiplodia theobromae Pat., an endophytic fungus, against 7, 12 dimethyl benz(a) anthracene (DMBA)-induced mammary gland carcinogenesis in Sprague dawley rats. Biomed \& Pharmacother. 64:48-53. doi:10.1016/j. biopha.2009.03.001.

Pawar VP. 2012. Impact of ecological factors on development of Botryodiplodia rot of guava fruit. Curr Bot. 3(3):16.

Purwandari U, Arifin S, Tamam B, Hidayati D. 2014b. Gluten- free noodle made from gathotan (an Indonesian fungal fermented cassava) flour: cooking quality, textural, and sensory propertis. Int Food Res J. 21(4):1615-1621.

Purwandari U, Khoiri A, Muchlis M, Noriandita B, Zeni NF, Lisdayana N, Fauziyah, E. 2014a. Textural, cooking quality, and sensory evaluation of gluten-free noodle maden from breadfruit, konjac, or pumpkin flour. Int Food Res J. 21(4):1623-1627.

Purwandari U, Tristiana GR, Hidayati D. 2014c. Gluten-free noodle made from gathotan flour: antioxidant activity and effect of consumption on blood glucose level. Int Food Res J. 21(4):1629-1634.

Purwandari U. 2000. Aflatoxin in gathotan in relation to fungal distribution. Master Thesis. Royal Melbourne Institute of Technology University.

Rajkovic MB, Novakovic ID, Petrovic A. 2007. Determination of titratable acidity in white wine. $\mathrm{J}$ Agric Sci. 52(2):169-184.

Sajitha KL, Florence EJM, Dev SA. 2014. Screening of bacterial biocontrol against sapstain fungus (Lasiodiplodia theobromae Pat.) of rubberwood (Hevea brasiliensis Muell. Arg.). Res in Microbiol. 165:541-548. http://dx.doi.org/10. 1016/j.resmic. 2014.07.002.

Sivakumar D, Jiang Y, Yahia EM. 2011. Maintaining mango (Mangifera indica L.) fruit quality during the export chain. Food Res Int. 44:1254-1263. doi:10.1016/ j.foodres.2010.11.022.

Uduebo AE, Madelin MF. 1974. Germination of conidia of Botryodiplodia theobromae in relation to age and environment. Trans Br Mycol Soc. 63(1):33-34. 
Vasconcelos AFD, Dekker RFH, Barbosa AM, Carbonero ER, Silveira JIM, Glauser B, Pereira MS, da Silva MLC. 2013. Sulfonation and anticoagulant activity of fungal exocellular b-(16)-D-glucan (lasiodiplodan). Carbohydr Polym. 92:1908-1914. http://dx.doi.org/ 10.1016/j.carbpol.2012.10.034. 